報 文

\title{
貯蔵トウモロコシにおけるアリルイソチオシアネート蒸気暴露による アフラトキシン蓄積制御と貯蔵性菌類の増殖への影響
}

(平成 26 年 7 月 4 日受理)

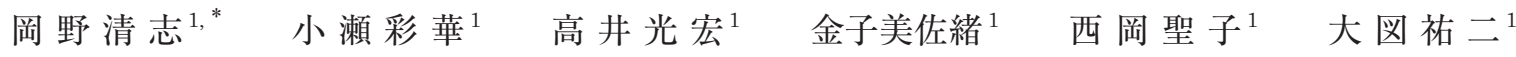 \\ 小田野正義 ${ }^{1}$ 関山泰司 ${ }^{2}$ 水上勇 - $^{2}$ 中村信 也 ${ }^{1,3}$ 一戸正勝 ${ }^{1,3}$
}

Inhibition of Aflatoxin Production and Fungal Growth on Stored Corn by Allyl Isothiocyanate Vapor

Kiyoshi OKano ${ }^{1,}$, , Ayaka Ose ${ }^{1}$, Mitsuhiro TakaI ${ }^{1}$, Misao KaneKo ${ }^{1}$, Chikako Nishioka ${ }^{1}$, Yuji Ohzu ${ }^{1}$, Masayoshi Odano ${ }^{1}$, Yasushi Sekryama ${ }^{2}$, Yuichi Mizukami ${ }^{2}$, Nobuya NAKAMURA ${ }^{1,3}$ and Masakatsu ICHINOE ${ }^{1,3}$

\footnotetext{
${ }^{1}$ Mycotoxin Research Association: 15 Daikoku Futo, Tsurumi-ku, Yokohama 230-0054, Japan;

${ }^{2}$ Mitsubishi-Kagaku Foods Corporation: PALACE Building, 1-1 Marunouchi 1-chome, Chiyoda-ku, Tokyo 100-8251, Japan;

${ }^{3}$ Tokyo Kasei University: 1-18-1 Kaga, Itabashi-ku, Tokyo 173-8602, Japan;

*Corresponding author
}

\begin{abstract}
Studies were conducted to determine the effectiveness of allyl isothiocyanate (AIT) vapor treatment with a commercial mustard seed extract (Wasaouro ${ }^{\circledR}$ ) in controlling aflatoxin-producing fungi on stored corn. The concentration of AIT in the closed container peaked at $54.6 \mathrm{ng} / \mathrm{mL}$ on the 14 th day and remained at $21.8 \mathrm{ng} / \mathrm{mL}$ on the $42 \mathrm{nd}$ day. AIT inhibited visible growth of aflatoxigenic molds in unsterilized corn and in sterilized corn inoculated with various aflatoxigenic fungi. However, fungi such as Aspergillus glaucus group, A. penicillioides and A. restrictus were detected by means of culture methods.
\end{abstract}

(Received July 4, 2014)

Key words: アリルイソチオシアネート allyl isothiocyanate (AIT); アフラトキシン aflatoxin; Aspergillus flavus; Aspergillus parasiticus; 貯蔵性菌類 storage fungi

\section{緒言}

アリルイソチオシアネート（AIT） はワサビやカラシな どのアブラナ科植物に含まれる配糖体のシニグリンがミロ シナーゼ酵素により加水分解され, 生成する揮発性抗菌性 物質である．既存添加物の「カラシ抽出物」は主成分とし てAITを高濃度に含んでおり ${ }^{1}$ ，すでに製造用剤（日持ち 向上剤）として商品化されている2).これらの商品は主に 各種加工食品の微生物制御の目的で用いられている.

AIT蒸気による細菌, 酵母, カビ類に対する抗菌性につ いては Inouye $ら^{3)}$, Isshiki ${ }^{4)}$, Sekiyama ら ${ }^{5)} に よ り$ 報 告されている. カビ毒産生菌類であるAspergillus flavus,

* 連絡先：mra-mycotoxin@yokohama.email.ne.jp

1 一般財団法人マイコトキシン検査協会：％230-0054 横浜 市鶴見区大黒ふ頭 15

${ }^{2}$ 三菱化学フーズ株式会社：テ100-8251東京都千代田区丸の 内 $1-1-1$

3 東京家政大学： $7173-8602$ 東京都板橋区加賀 1-18-1
Penicillium islandicum, P. citrinum, Fusarium graminearumなどの菌類についても平板培養によるAITの最 少発育阻止濃度 (MIC) は報告 ${ }^{4)}$ されているが, 実際の 農産物を用いた系でのこれら菌類の発育抑制およびカビ毒 生成の抑制効果についての報告はいまだ少ない.

われわれは，加工食品分野以外への AIT製剤の応用の可 能性について, カビ毒污染の知られる農産物 (穀類, 種実 類, 油糧種子, 香辛料) への $\mathrm{AIT}$ 適用の基礎的検討の一環 として, カビ毒の代表であるアフラトキシンを産生する $A$. flavus, A. parasiticus をトウモロコシ穀粒に接種後，常温 密封条件下で保存し, 経時的なAIT蒸気の濃度変化, 接種 菌の増殖とそれに伴うアフラトキシン（AFs）蓄積の抑制, およびAITによる貯蔵性菌類への影響などの検討を行った。

\section{実 験 方 法}

\section{1. 被験農産物}

フランスより輸入した 2012 年産イエローデントコーン 
（non-GMO）をふるい選別した後に実体顕微鏡下で破損 粒，変色粒などの不良品を除去し，健全粒のみを選んで試 験用トウモロコシとした。試験用トウモロコシは $A$. flavus とA. parasiticusの污染がないこと，またAFs 污染が ないことをあらかじめ確認した。このトウモロコシを $121^{\circ} \mathrm{C}$ で 15 分間滅菌したもの（滅菌トウモロコシ）と滅菌 しないトウモロコシ（非滅菌トウモロコシ）を試験に用い た。ちなに供試したトウモロコシの水分活性 $\left(A_{\mathrm{w}}\right)$ は 0.83 であった.

\section{2. 被験菌}

\section{1 供試 $\mathrm{AF}$ 産生菌株}

接種菌として使用したA. flavus（C-1）およびA. parasiticus（C-3）はアメリカ産トウモロコシ由来の菌株で, あらかじめ $2 \%$ 酵母エキス・ $15 \%$ シュウクロース液体培地 に培養後, $\mathrm{AF}$ 産生能を有することを薄層クロマトグラ フィーで確認した.

\section{2 接種菌調製}

ポテトデキストロース寒天斜面培地に供試菌を 1 週間, $25^{\circ} \mathrm{C}$ で培養した後, 界面活性剂を添加した滅菌希釈液を 約 $5 \mathrm{~mL}$ 加え, 滅菌綿棒にて菌体表面をこすり, 分生子を 遊離させた後に滅菌ガーゼでろ過し, 胞子懸濁原液を作製 した ${ }^{6)}$. 胞子懸濁液は, 適宜希釈してセルカウンター（ワ ンセル(株) 製：広島市）にて $10^{5}$ 分生子 $/ \mathrm{mL}$ になるように 調製した。

\section{3. 試料調製および保存方法}

\section{1 試験容器}

嫌気培養用のアネロパック角形ジャー（三菱ガス化学 （株））を密封容器として使用した。容器内の隔壁部分には 相対湿度調整用の塩化バリウム飽和溶液（RH 90.1\%）お よびAIT蒸気の放出に用いるAIT含有製剤（ワサオーロ ${ }^{\circledR}$

VS15 L- II 三菱化学フーズ(株)製）を収納した（AIT適 用)。また容器内のAIT蒸気の濃度を経時的に測定するた め, 別途ガスタイトジョイント付き容器にて同一の調製を 行った。同じ条件でAIT含有製剤の入れない容器を対照 とした.

\section{2 被験菌接種方法}

滅菌済群と非滅菌群のそれぞれから試料トウモロコシ $30 \mathrm{~g}$ ずつを 4 枚のガラスシャーレ（高さ $2.5 \mathrm{~cm}$, 外径

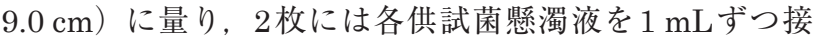
種してよく混和した．対照として 1 枚に希釈液のみ $1 \mathrm{~mL}$ を加えよく混和し，残りの1枚は未接種とした。

トウモロコシを入れたシャーレはガラスぶたに代えてガ ス透過性を有するポリ塩化ビニル製7) ラップで接種菌同 士の污染を防ぐためシャーレを覆った。これら調整後の容 器は $25^{\circ} \mathrm{C}$ に調整した恒温器に入れ最長 42 日間保存した.

3.3 試験容器の種類と数

今回の試験に供した密封容器の条件とシャーレの数につ いてはTable 1 に示したとおりである。すなわち，AIT製 剤入り接種試験容器 (AIT適用区) 7, 14, 28, 42 日の 4 個

Table 1. Experiments to determine aflatoxin production by allyl isothiocyanate-treated corn kernels

\begin{tabular}{|c|c|c|c|c|c|c|c|}
\hline \multirow{3}{*}{ Group } & \multirow{3}{*}{ Materials } & \multirow{3}{*}{$\begin{array}{l}\text { Container } \\
\text { number }\end{array}$} & \multirow{3}{*}{$\begin{array}{l}\text { Storage period } \\
\quad \text { (day) }\end{array}$} & \multicolumn{4}{|c|}{ Number of test petri dishes } \\
\hline & & & & \multirow{2}{*}{$\begin{array}{l}\text { Inoculate } \\
\text { A. parasiticus } \\
(1 \mathrm{~mL})\end{array}$} & \multirow{2}{*}{$\begin{array}{l}\text { Inoculate } \\
\text { A. flavus } \\
(1 \mathrm{~mL})\end{array}$} & \multicolumn{2}{|c|}{ Control kernels } \\
\hline & & & & & & $\begin{array}{l}\text { Diluent only } \\
\quad(1 \mathrm{~mL})\end{array}$ & Only corn \\
\hline \multirow[t]{8}{*}{ AIT } & Sterilized corn & J01 & 7 & 1 & 1 & 1 & 1 \\
\hline & & J02 & 14 & 1 & 1 & 1 & 1 \\
\hline & & J03 & 28 & 1 & 1 & 1 & 1 \\
\hline & & J04 & 42 & 1 & 1 & 1 & 1 \\
\hline & Non-sterilized corn & J05 & 7 & 1 & 1 & 1 & 1 \\
\hline & & J06 & 14 & 1 & 1 & 1 & 1 \\
\hline & & J07 & 28 & 1 & 1 & 1 & 1 \\
\hline & & J08 & 42 & 1 & 1 & 1 & 1 \\
\hline \multirow[t]{8}{*}{ Without AIT } & Sterilized corn & J09 & 7 & 1 & 1 & 1 & 1 \\
\hline & & J10 & 14 & 1 & 1 & 1 & 1 \\
\hline & & J11 & 28 & 1 & 1 & 1 & 1 \\
\hline & & J12 & 42 & 1 & 1 & 1 & 1 \\
\hline & Non-sterilized corn & J13 & 7 & 1 & 1 & 1 & 1 \\
\hline & & J14 & 14 & 1 & 1 & 1 & 1 \\
\hline & & J15 & 28 & 1 & 1 & 1 & 1 \\
\hline & & J16 & 42 & 1 & 1 & 1 & 1 \\
\hline \multirow[t]{3}{*}{ AIT monitoring } & Air & J17* & $3 \mathrm{hr}, 1,7,14,28,42$ & 0 & 0 & 0 & 0 \\
\hline & Non-sterilized corn & J18* & $3 \mathrm{hr}, 1,7,14,28,42$ & 0 & 0 & 3 & 1 \\
\hline & Non-sterilized corn & J19* & $3 \mathrm{hr}, 1,7,14,28,42$ & 1 & 1 & 1 & 1 \\
\hline $\begin{array}{l}\text { Without AIT } \\
\text { monitoring }\end{array}$ & Non-sterilized corn & J20* & $3 \mathrm{hr}, 1,7,14,28,42$ & 0 & 0 & 0 & 4 \\
\hline
\end{tabular}

\footnotetext{
* Collect gas via gas—tight joint from each container
} 
とAIT製剤の適用なし接種試験容器（対照区） 7, 14, 28, 42 日の 4 個を滅菌卜ウモロコシおよび非滅菌卜ウモロコ シ試験用の同数を試験用とした。またAIT蒸気濃度の変 化を測定するためにAIT製剤のみを収納した容器 1 個, AIT 製剂入り非滅菌トゥモロコシ入りガラスシャーレ（3 枚に希釈液のみを各 $1 \mathrm{~mL}$ 接種, 1 枚を未接種) 容器 1 個 および非滅菌トウモロコシ入りシャーレ（未接種 4 枚）容 器 1 個の 3 種を試験用とした.

\section{4. 容器内AIT 蒸気濃度の測定}

4.1 測定時期

非滅菌トゥモロコシの AIT 適用区と AIT 蒸気濃度測定 の対照とした 3 種の容器内 AIT 蒸気濃度を試験初発日, 1 , 7，14，28，42 日経過後についてそれぞれを測定した.

\subsection{AIT 蒸気濃度測定方法}

\subsection{1 標準液調製と容器内ガス濃度測定}

標準品イソシアン酸アリル（和光純薬工業(株) 製特級） を n-ヘキサン（和光純薬工業(株) 製特級）にて希釈して $10 \mu \mathrm{g} / \mathrm{mL}, 100 \mu \mathrm{g} / \mathrm{mL}, 1000 \mu \mathrm{g} / \mathrm{mL}$ の濃度に調製した標準 液の $1 \mu \mathrm{L}$ 各 2 点ずつ GC-FIDに注入し, 各濃度のピーク 面積を平均して検量線を作成した. AIT測定用容器のガス タイトジョイントからガスタイトシリンジを用い容器内の ガス $1 \mathrm{~mL}$ 各 2 点ずつ注入し, 各ピーク面積の平均を AIT ガス濃度とした.

4.2.2 装置

GC-FID: GC4000 (GL Sciences 社製)，カラム：HP$5 \mathrm{MS}(0.25 \mathrm{~mm}$ i. d. $\times 30 \mathrm{~m}$, 膜厚 $0.25 \mu \mathrm{m}$, Agilent社製 $)$, カラム温度： $40^{\circ} \mathrm{C}(5 \mathrm{~min}) \rightarrow 5^{\circ} \mathrm{C} / \mathrm{min} \rightarrow 85^{\circ} \mathrm{C} \rightarrow 20^{\circ} \mathrm{C} / \mathrm{min} \rightarrow$ $200^{\circ} \mathrm{C}$, 注入口温度: $200^{\circ} \mathrm{C}$, 検出器温度: $200^{\circ} \mathrm{C}$, 注入量: 標準液 $1 \mu \mathrm{L}$, ガス $1 \mathrm{~mL}$ (スプリット比約 $1: 19)$, カラムガ ス流量： $1.0 \mathrm{~mL} / \mathrm{min}$, キャリヤーガス: ヘリウム

\section{5. 目視によるカビの発育状況観察}

各試験時期におけるトウモロコシ款粒のカビ類の発育に ついては, 菌数測定用の粉砕に先立って, ラップを装着し たまま目視と実体顕微鏡下で穀粒表面の菌糸体の生育およ びAspergillus類の胞子形成器官について観察した.

\section{6. 菌数測定法}

6.1 滅菌トウモロコシにおける接種菌数測定

保存期間を経過したトウモロコシ $30 \mathrm{~g}$ を Oster Blender にて粉挽し，その $10 \mathrm{~g}$ を $0.1 \%$ ペプトン水にて 10 倍段階希 釈液を調製し, 各希釈液の $0.5 \mathrm{~mL} 2$ 枚の DRBC 培地 (Oxoid社製) の平板表面に塗抹し $25^{\circ} \mathrm{C}, 7$ 日間培養して出 現した接種菌の集落を計測し $1 \mathrm{~g}$ 当たりの菌数（CFU）を 測定した.

6.2 非滅菌トウモロコシおける接種菌数抒よび自然着 生菌数測定

保存期間を経過したトウモロコシを上記の 6.1 と同様に 粉砕し, その $10 \mathrm{~g}$ を量り, 希釈液を調製して各段階希釈 液の $0.5 \mathrm{~mL}$ DRBC 培地および好乾性菌類の選択培地で あるDG18培地（Oxoid社製）の平板培地に2枚ずつ表面 塗抹した。ついで $25^{\circ} \mathrm{C} て ゙ 7$ 日間培養後, 接種菌拈よび $A$.

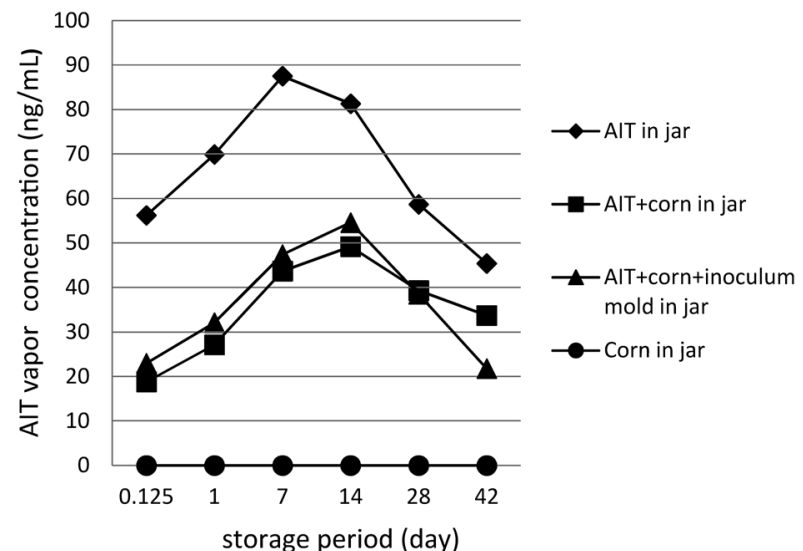

Fig. 1. Changes in concentration of allyl isothiocyanate (AIT) during storage

$\boldsymbol{\nabla}$, AIT in jar (container) J17; $\mathbf{\square}$, AIT + corn (with diluent) in container (J18); $\boldsymbol{\Delta}$, AIT + corn +inoculum mold in container (J19); $\bigcirc$, corn in container (J20)

glaucus 菌群, A. penicillioides, A. restrictusなどの貯蔵 性菌類を識別・菌数測定をし, 菌数は必要に応じて対数に 換算した.

\section{7. 蓄積 $\mathrm{AFs}$ の測定}

保管期間を経過し，粉砕した試料の $20 \mathrm{~g}$ について $\mathrm{AF}$ 通 知分析法 ${ }^{8}$ に準拠して $\mathrm{AFB}_{1}, \mathrm{~B}_{2}, \mathrm{G}_{1}, \mathrm{G}_{2}$ の各濃度を測定し た。

\section{結 果}

\section{1. 容器内AIT 蒸気濃度の変化}

容器内に入れたAIT製剤から保存中に放出したAIT蒸 気濃度の変化について, 製剂のみを入れた（AIT適用）容 器, トゥモロコシを入れた容器, $\mathrm{AF}$ 産生菌を接種した容 器のおのおのにつき対照区と比較して Fig. 1に示した.

使用したAIT製郕のワサオーロ ${ }^{\circledR} \mathrm{VS} 15$ L- II は，AITを 含浸させたセルロースビーズを分包した製郕でAIT蒸気 の放出期間は約 1 か月に設計されている.

AIT 濃度測定は， $x$ 軸を標準液濃度とし $y$ 軸にそのピー ク面積とした。回帰線は $y=769 x-2841$ で相関係数は $r=$ 0.999であった，定量限界は $2 \mathrm{ng} / \mathrm{mL}$ であった，AIT製剤 のみを入れた場合の容器内 AIT濃度は 7 日目の $87.5 \mathrm{ng} /$ $\mathrm{mL}$ をピークとし徐々に減少したが，保存終了時の 42 日 目でも $45.4 \mathrm{ng} / \mathrm{mL}$ を維持していた。一方，トウモロコシ を入れた容器内の AIT濃度はAIT製剤のみを入れた容器 の約 $1 / 2$ 程度となり，14日目の $49.2 \mathrm{ng} / \mathrm{mL}$ をピークとし 徐々に減少した。カビ接種区では 14 日目の $54.6 \mathrm{ng} / \mathrm{mL}$ ピークとし 42 日目で $21.8 \mathrm{ng} / \mathrm{mL}$ まで減少した。容器を開 けた直後はカラシ臭が僅かにあったがすぐに消え，トウモ ロコシへのカラシ臭の残存もなかった. 
Table 2. Inhibition of aflatoxin formation and growth of inoculated Aspergillus parasiticus on sterilized corn by allyl isothiocyanate vapor

\begin{tabular}{|c|c|c|c|c|c|c|c|c|}
\hline \multirow{2}{*}{$\begin{array}{l}\text { Storage period } \\
\text { (day) }\end{array}$} & \multirow{2}{*}{$\begin{array}{l}\text { Container } \\
\text { number }\end{array}$} & \multirow{2}{*}{ Condition } & \multirow{2}{*}{$\begin{array}{l}\text { Visible growth } \\
\text { of fungi }\end{array}$} & \multirow{2}{*}{$\begin{array}{l}\text { A. parasiticus } \\
\text { growth } \mathrm{CFU} / \mathrm{g}\end{array}$} & \multicolumn{4}{|c|}{ Aflatoxin (ng/g) } \\
\hline & & & & & $\mathrm{B}_{1}$ & $\mathrm{~B}_{2}$ & $\mathrm{G}_{1}$ & $\mathrm{G}_{2}$ \\
\hline Control & & & - & - & ND & ND & ND & ND \\
\hline Initial & & & - & $1.0 \times 10^{2}$ & 0.6 & $\mathrm{ND}$ & 0.3 & 0.1 \\
\hline \multirow[t]{2}{*}{7} & J01 & AIT & - & $2.0 \times 10^{2}$ & 0.5 & ND & 0.2 & ND \\
\hline & J09 & without AIT & + & $9.0 \times 10^{2}$ & 4.3 & 0.2 & 22.6 & 1.3 \\
\hline \multirow[t]{2}{*}{14} & J02 & AIT & - & $2.0 \times 10^{2}$ & 0.5 & ND & 0.2 & 0.1 \\
\hline & $\mathrm{J} 10$ & without AIT & + & $1.1 \times 10^{4}$ & 327 & 34.6 & 3,540 & 461 \\
\hline \multirow[t]{2}{*}{28} & J03 & AIT & - & - & 0.6 & ND & 0.3 & 0.1 \\
\hline & $\mathrm{J} 11$ & without AIT & + & $2.7 \times 10^{6}$ & 2,120 & 434 & 32,400 & 867 \\
\hline \multirow[t]{2}{*}{42} & J04 & AIT & - & - & 0.4 & ND & 0.1 & ND \\
\hline & J12 & without AIT & + & $2.8 \times 10^{5}$ & 1,450 & 148 & 23,400 & 8,470 \\
\hline
\end{tabular}

Visible growth of inoculated fungi: — no growth, + growth, A. parasiticus - - less than $10^{1} \mathrm{CFU} / \mathrm{g}$; ND: Aflatoxin detection limit $0.1 \mathrm{ng} / \mathrm{g}$

Table 3. Inhibition of aflatoxin formation and growth of inoculated Aspergillus flavus on sterilized corn by allyl isothiocyanate vapor

\begin{tabular}{|c|c|c|c|c|c|c|c|c|}
\hline \multirow{2}{*}{$\begin{array}{l}\text { Storage period } \\
\text { (day) }\end{array}$} & \multirow{2}{*}{$\begin{array}{l}\text { Container } \\
\text { number }\end{array}$} & \multirow{2}{*}{ Condition } & \multirow{2}{*}{$\begin{array}{c}\text { Visible growth } \\
\text { of fungi }\end{array}$} & \multirow{2}{*}{$\begin{array}{c}\text { A. flavus } \\
\text { growth } \mathrm{CFU} / \mathrm{g}\end{array}$} & \multicolumn{4}{|c|}{ Aflatoxin (ng/g) } \\
\hline & & & & & B1 & $\mathrm{B} 2$ & $\mathrm{G}_{1}$ & $\mathrm{G}_{2}$ \\
\hline Control & & & - & - & $\mathrm{ND}$ & ND & ND & $\mathrm{ND}$ \\
\hline Initial & & & - & $3.2 \times 10^{3}$ & 0.4 & 0.1 & ND & ND \\
\hline \multirow[t]{2}{*}{7} & J01 & AIT & - & $1.0 \times 10^{2}$ & 0.4 & ND & ND & ND \\
\hline & J09 & without AIT & + & $4.0 \times 10^{3}$ & 0.3 & $\mathrm{ND}$ & ND & ND \\
\hline \multirow[t]{2}{*}{14} & J02 & AIT & - & - & 0.3 & ND & ND & ND \\
\hline & J10 & without AIT & + & $2.6 \times 10^{5}$ & 386 & 34.7 & ND & ND \\
\hline \multirow[t]{2}{*}{28} & J03 & AIT & - & - & 0.4 & ND & ND & ND \\
\hline & J11 & without AIT & + & $2.1 \times 10^{6}$ & 1110 & 185 & ND & $\mathrm{ND}$ \\
\hline \multirow[t]{2}{*}{42} & J04 & AIT & - & - & 0.3 & ND & ND & ND \\
\hline & J12 & without AIT & + & $6.2 \times 10^{6}$ & 945 & 169 & ND & $\mathrm{ND}$ \\
\hline
\end{tabular}

Visible growth of inoculated fungi: - no growth, + growth A. flavus -: less than $10^{1}$ CFU/g; ND: Aflatoxin detection limit $0.1 \mathrm{ng} / \mathrm{g}$

\section{2. $\mathrm{AF}$ 産生菌を接種した滅菌トウモロコシのカビ発育 と $\mathrm{AFs}$ 蓄積抑制効果}

\subsection{A. parasiticus 接種試験}

A. parasiticus 菌株の分生子懸濁液を接種した滅菌トウ モロコシについて, AIT適用区とAITを適用していない対 照区における接種菌の発育およびAFsの蓄積に対する AITの影響を調べた結果をTable 2 に示した.

この接種試験で用いた懸濁液 $1 \mathrm{~mL}$ 中の分生子数は $3.6 \times$ $10^{5}$ 個で, $A F s$ 濃度は $B_{1} 27.7 \mathrm{ng}, \mathrm{B}_{2} 0.7 \mathrm{ng}, \mathrm{G}_{1} 7.9 \mathrm{ng}, \mathrm{G}_{2}$ $0.2 \mathrm{ng}$ であった.

\section{1 .1 目視による菌糸等の発育}

Table 2 に示したように対照区では接種菌の菌糸体が7 日目から見られ，14日目以降には豊富な胞子形成が見ら れた.これに伴い検出菌数も $10^{3}$ から $10^{5} \mathrm{CFU} / \mathrm{g}$ レベルに 増加した。一方, AIT適用区では 42 日目まで菌体の発育 は目視では見られず, 14 日目まで検出した菌数の $10^{2} \mathrm{CFU} / \mathrm{g}$ は接種菌が残存したもので以降の発育は認めら
れなかった。

\subsection{2 $\mathrm{AFs}$ の蓄積}

対照区では7日目からの菌体の増殖とともに $\mathrm{AFs}$ の蓄積 が認められ， 14 日目以降 $\mathrm{G}_{1}$ の蓄積が増大した， 42 日目に おける $\mathrm{AFs}$ の減少は分解現象によるものと推定された. 一方, AIT適用区では AFs の増加は認められず，接種菌液 由来とする $1.0 \mathrm{ng} / \mathrm{g}$ 未満の微量な $\mathrm{AFs}$ の検出が見られたに すぎなかった。

\subsection{A. flavus 接種試験}

A. flavus 菌株の分生子懸濁液を接種した滅菌トウモロ コシについて，A. parasiticus と同様にAIT適用区と対照 区での接種菌の発育およびAFs 蓄積に対する影響を検討 した結果をTable 3 に示した.

接種試験で用いた懸濁液 $1 \mathrm{~mL}$ 中の分生子数は $4.8 \times 10^{5}$

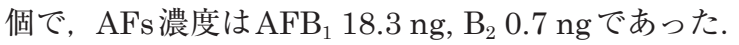

2.2 .1 目視による菌糸等の発育

対照区では 7 日目から菌の増殖が見られ，14日目以降に 
Table 4. Inhibition of aflatoxin production and growth of inoculated fungi and naturally occurring fungi in corn by allyl isothiocyanate vapor

\begin{tabular}{|c|c|c|c|c|c|c|c|c|c|}
\hline \multirow{2}{*}{$\begin{array}{l}\text { Inoculated } \\
\text { fungi }\end{array}$} & \multirow{2}{*}{$\begin{array}{c}\text { Storage } \\
\text { period } \\
\text { (day) }\end{array}$} & \multicolumn{2}{|c|}{ AFs production } & \multicolumn{2}{|c|}{ Visible growth } & \multicolumn{2}{|c|}{ Inoculum CFU/g* } & \multicolumn{2}{|c|}{$\begin{array}{c}\text { Aspergillus glaucus } \\
\text { CFU } / \mathrm{g}^{*}\end{array}$} \\
\hline & & $\begin{array}{l}\text { Without } \\
\text { AIT }\end{array}$ & $\mathrm{AIT}$ & $\begin{array}{l}\text { Without } \\
\text { AIT }\end{array}$ & $\mathrm{AIT}$ & $\begin{array}{l}\text { Without } \\
\text { AIT }\end{array}$ & $\mathrm{AIT}$ & $\begin{array}{l}\text { Without } \\
\text { AIT }\end{array}$ & $\mathrm{AIT}$ \\
\hline \multirow[t]{5}{*}{ Aspergillus parasiticus } & Initial & ND & ND & - & - & $2.0 \times 10^{2}$ & $2.0 \times 10^{2}$ & - & - \\
\hline & 7 & ND & ND & + & - & - & $2.0 \times 10^{2}$ & - & $6.8 \times 10^{3}$ \\
\hline & 14 & ND & ND & ++ & - & - & - & $3.6 \times 10^{5}$ & $1.0 \times 10^{2}$ \\
\hline & 28 & ND & ND & ++ & - & - & - & $2.1 \times 10^{5}$ & $4.8 \times 10^{3}$ \\
\hline & 42 & ND & ND & ++ & - & - & - & $8.0 \times 10^{6}$ & $4.0 \times 10^{4}$ \\
\hline \multirow[t]{5}{*}{ Aspergillus flavus } & Initial & $\mathrm{ND}$ & ND & - & - & $1.0 \times 10^{2}$ & $1.0 \times 10^{2}$ & $4.4 \times 10^{3}$ & $4.4 \times 10^{3}$ \\
\hline & 7 & ND & ND & + & - & - & $1.2 \times 10^{3}$ & $2.0 \times 10^{3}$ & $1.2 \times 10^{3}$ \\
\hline & 14 & ND & ND & ++ & - & - & - & $2.2 \times 10^{5}$ & $2.0 \times 10^{3}$ \\
\hline & 28 & ND & ND & ++ & - & - & - & $6.8 \times 10^{4}$ & $9.5 \times 10^{4}$ \\
\hline & 42 & ND & ND & ++ & - & - & - & $9.0 \times 10^{5}$ & $8.0 \times 10^{4}$ \\
\hline
\end{tabular}

Without AIT, container number: 7 (J13), 14 (J14), 28 (J15), 42 (J16)

AIT, container number: 7 (J05), 14 (J06), 28 (J07), 42 (J08)

ND: AFs production, Total AFs detection limit $0.4 \mathrm{ng} / \mathrm{g}$, Visible growth of fungi: - no growth, + limited growth, ++ growth

Inoculum CFU/g: AF producting fungi counts, - less than $10^{1} \mathrm{CFU} / \mathrm{g}$, A. glaucus CFU/g: - less than $10^{1} \mathrm{CFU} / \mathrm{g}$

* $\mathrm{CFU} / \mathrm{g}$ detected in DRBC medium

は豊富な胞子形成が認められた。また，検出菌数も $10^{5}$ か ら $10^{6} \mathrm{CFU/g}$ レベルに増加した。

一方，AIT適用区では 42 日目まで発育は目視では認め られず, 菌数も 7 日目に検出した残存接種菌由来の $1.0 \times$ $10^{2} \mathrm{CFU} / \mathrm{g}$ 以降，増殖は認められなかった。

\section{$2.2 .2 \mathrm{AFs}$ の蓄積}

対照区では7日目から菌体の増殖が始まり，14日目から $\mathrm{AFB}_{1}, \mathrm{~B}_{2}$ の蓄積が認められA. parasiticusより遅れて増加 したが，42日目にはAFsの減少が見られた。一方，AIT 適用区では $\mathrm{AFs}$ の増加は認められず, 接種菌液由来とす る $0.5 \mathrm{ng} / \mathrm{g}$ 末満の微量な $\mathrm{AFs}$ の検出をみたのみであった.

\section{3. 非滅菌トウモロコシにおける接種菌の発育抑制効果 ならびに唄蔵性菌類に対する影響}

農産物への AIT 製剤の利用を想定して行った予備試験 で，貯蔵されたトウモロコシにAF産生菌を接種してAIT 製郕を適用した場合に接種菌が発育せず， $\mathrm{AFs}$ 蓄積の増加 も認められなかったにもかかわらず一部の貯蔵性菌類が生 残したことから，貯蔵時等に㧍ける着生カビの増殖を想定 してAIT製片による接種菌および貯蔵性菌類の増殖抑制 を検証する目的で以下の実験を行った。

3.1 非滅菌卜ウモロコシにおける $\mathrm{AF}$ 産生接種菌の発 育と $\mathrm{AF}$ 蓄積抑制効果㧍よび検出した貯蔵菌類に対す る影響

非滅菌トウモロコシを用いAIT 適用区と対照区の各保 存期間に扔ける $\mathrm{AF}$ 産生菌の $\mathrm{AFs}$ 蓄積とカビ類の発育の影 響を目視による発育の観察とDRBC 培地と好乾性菌類選 択培地のDG18培地を併用して培養試験を行った。

DRBC培地による菌数測定の結果をTable 4 に示した. 接種した $\mathrm{AF}$ 産生菌のA. parasiticusの懸濁液 $1 \mathrm{~mL}$ 中の分

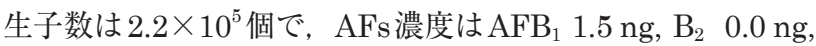
$\mathrm{G}_{1} 2.2 \mathrm{ng}, \mathrm{G}_{2} 0.1 \mathrm{ng}$ であった. A. flavusの懸濁液 $1 \mathrm{~mL}$ 中

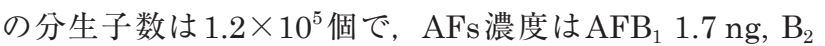
$0.1 \mathrm{ng}$ であった。

AIT適用区は，目視によるカビの発育は認められず，対 照区のみ目視によるトウモロコシ表面にカビの増殖が認め られた。発育したカビ集落は, 形態観察と培養試験により 貯蔵性菌類のA. glaucus 菌群であることを確認した。

一方，対照のAIT 非適用区では実体顕微鏡による観察 でトウモロコシ表面に A. penicillioides, A. restrictusの特 徵的な発育を認めた。

Table 4に示したように接種した $\mathrm{AF}$ 産生菌は, 対照区 では 7 日以降の検出はなく, AIT適用区では 14 日以降の 検出はなかった，AIT適用区のみならず対照区においても 接種菌の発育は認められなかったことから $\mathrm{AFs}$ の蓄積も なく, 接種菌を由来とする $0.4 \mathrm{ng} / \mathrm{g}$ 未満の微量な $\mathrm{AFs}$ の検 出が見られたにすぎなかった。

培養試験で検出されたA. glaucus 菌群は, AIT適用区で は対照区と比べ菌数に若干の減少が認められた.

培養試験はDRBC 培地とDG18培地とを併用して行っ たが，DRBC培地ではA. glaucus菌群以外の貯蔵性菌類 は検出できず，主にDG18培地で検出したのは好乾性貯蔵 菌の, DRBC培地でも検出したA. glaucus 菌群とA. penicillioides とA. restrictusであった。それぞれの菌数測定 を行い，AIT蒸気による影響を接種菌ごとに時間経過によ る減少傾向を見るために CFU/g を対数に変換して Fig. 2 およびFig. 3に示した.

DG18培地で検出した接種菌の菌数はAIT適用区，対照区 ともにDRBC培地による結果と同様でA. parasiticusは7日 目まで $10^{2} \mathrm{CFU} / \mathrm{g}$ 検出し, A. flavusは 14 日まで $10^{3} \mathrm{CFU} / \mathrm{g}$ を検出した以降，検出されなかった。

貯蔵性菌類の保存期間に扔けるAIT蒸気に対する影響 は，接種菌の種類とはかかわりなく同様の抑制効果を認め 


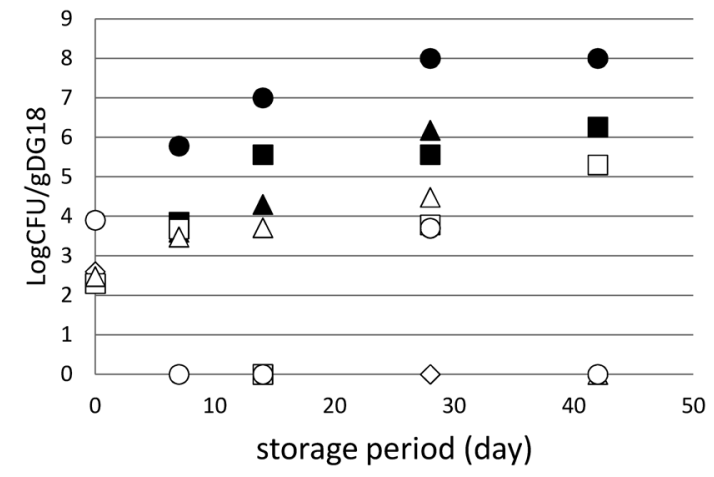

Fig. 2. Growth of naturally occurring fungi in corn, with and without AIT in a closed container

(White symbols: AIT, Black symbols: without AIT) inoculum Aspergillus parasiticus Container number: $\diamond, \square, \triangle, \bigcirc$ (J05, J06, J07, J08);
$\Delta,(\mathrm{J} 13, \mathrm{~J} 14, \mathrm{~J} 15, \mathrm{~J} 16)$
Inoculum A. parasiticus
A. glaucus
A. penicillioides
A. restrictus
$\checkmark$ AIT inoculum A. flavus
$\square$ AIT A. glaucus
$\triangle$ AIT A. penicillioides
$\bigcirc \operatorname{AIT} A$. restrictus

た。

DG18培地を用いて検出したA. glaucus 菌群の増殖の傾 向は, DRBC培地を用いた場合と同様で，対照区の $10^{6} \mathrm{CFU} / \mathrm{g}$ と比べて AIT適用区の $10^{5} \mathrm{CUF} / \mathrm{g}$ は若干の減少 を認めた。

A. penicillioidesは, 対照区では $10^{2}$ から $10^{6} \mathrm{CFU} / \mathrm{g}$ で増殖したが, AIT適用区では $10^{2}$ から $10^{4} \mathrm{CFU} / \mathrm{g}$ までの 菌数の検出にとどまり, 対照区よりも明らかに減少を認め た。

一方, A. restrictusの対照区では $10^{3}$ から $10^{6} \mathrm{CFU} / \mathrm{g}$ ま で増殖したがAIT適用区では初発菌のほか, A. parasiticus を接種した試験区において 28 日目に $10^{3} \mathrm{CFU} / \mathrm{g}$ 検出し た以外はほとんど検出されず，強い抑制効果が見られた。

\section{考察}

1. トウモロコシへの吸着による容器内のAIT濃度の 変化

Fig. 1 に示した密封容器内のAIT濃度がトウモロコシを 入れた状態で減少した現象については, Sekiyamaら ${ }^{22}$, 一色・徳岡 ${ }^{9)}$ がAIT蒸気下に食品を置くとその表面にAIT が吸着することを認めており，トウモロコシを入れた容器 内の AIT濃度がAITのみを入れた濃度の $1 / 2$ 程度の $50 \mathrm{ng} /$ $\mathrm{mL}$ 前後であったことはトウモロコシの表面にAITの一部 が吸着されたことが示唆された。

試験に供したAIT製剤は蒸気が1か月にわたり徐々に放 出されるように設計された徐放性の製品であり, 今回の試 験系における容器内のAIT濃度の実測值と, Isshiki ${ }^{4)}$ が密封したガラスシャーレで平板培養をした供試菌として

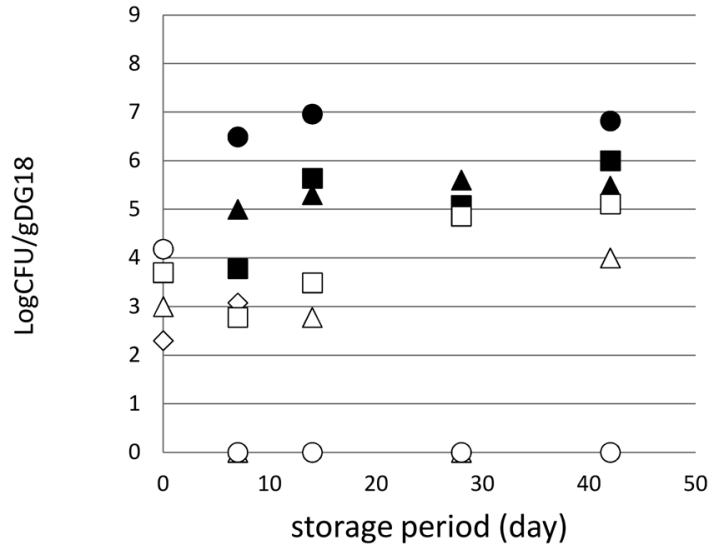

Fig. 3. Growth of naturally occurring fungi in corn, with and without AIT in a closed container

(White symbols: AIT, Black symbols: without AIT) inoculum Aspergillus flavus

Container number: $\diamond, \square, \triangle, \bigcirc$ (J05, J06, J07,

J08); $\boldsymbol{\square}, \boldsymbol{\bullet}(\mathrm{J} 13, \mathrm{~J} 14, \mathrm{~J} 15, \mathrm{~J} 16)$

$\checkmark$ Inoculum A. flavus

A. glaucus

A A. penicillioides

A. restrictus

$\checkmark$ AIT inoculum A. flavus

$\square$ AIT A. glaucus

$\triangle$ AIT A. penicillioides

$\bigcirc$ AIT A. restrictus

A. flavus菌株を用いたAITの最少生育阻止濃度（MIC） の $37 \mathrm{ng} / \mathrm{mL}^{4)}$ と今回のトウモロコシを用いた試験と抑制 濃度が近似して㧍り同等の効果であったことを認めた。

\section{2. 滅菌トウモロコシおよび非滅菌トウモロコシに接種} した $\mathrm{AF}$ 産生菌の発育抑制効果

代表的な $\mathrm{AF}$ 産生菌であるA. parasiticus, A. flavusを接 種した滅菌卜ウモロコシおよび非滅菌卜ウモロコシにおけ る発育抑制は，滅菌トウモロコシの AIT 適用区では表面 に付着した分生子等がAITにより発育抑制されたが，非 滅菌トウモロコシおける対照区の $\mathrm{AF}$ 産生菌の発育抑制 は, 貯蔵性菌類として着生しているA. glaucus 菌群など の増殖による菌同士の競合からくる抑制と考えられ，また AIT適用区に扔ける接種菌の発育抑制は，AITによる抑制 とAITに抵抗性を示す貯蔵性菌類との競合による抑制の 両方が考えられた。

\section{AITのトウモロコシに自然感染した貯蔵性菌類に対} する増殖抑制

非滅菌トウモロコシから検出した䝪蔵性菌類のA. glaucus 菌とA. penicillioides, A. restrictusに対するAITの抑 制効果は一定でなく菌の種類により差異があることが認め られた. Tsuruta ら ${ }^{10)}$ ，Fennell ら ${ }^{11)}$ はトウモロコシ款粒 が健全粒であればカビの侵入を阻止する働きを自ら持つと 報告している。 すなわち, Tsuruta ら ${ }^{10)}$ はトゥモロコシ 穀粒のEurotium chevalieri (A. glaucus 菌群) 等のカビ の侵入経路は果皮と胚の間隙から入り, Tip cap (尖帽部) から侵入し表層部分の Hilar layer (ハイラー層) を通過し 
内部の肧芽に広がると報告している。 それに対し同じ貯蔵 性菌のA. restrictusの感染は異なり, Hilar layerで肧芽へ の侵入が阻止されると報告している。また，Fennellら ${ }^{11)}$ はA. flavusについてトウモロコシの Hilar layer と Tip cap との間隙に菌核を作るが肧の内部への侵入は阻止され たと報告している。 一方, Takahashi ら ${ }^{12)}$ はA. restrictusについて玄米粒への内部侵入について, 菌系は肧芽部 と隣接するアリューロン細胞までは侵入するがデンプン胚 乳までは侵入しないと報告している。

今回の試験結果から AITによるA. restrictusへの強い増 殖抑制はこの菌が内部に侵入しにくい表在性の菌であった ために効果があったと考えられ，A. glaucus菌群について は内部に侵入しやすい性状のためにAITに抵抗したこと が示唆された.

しかし, 今回検出したA. penicillioidesについてはトウ モロコシ穀粒への侵入について文献上の情報がなく, 結果 から A. glaucus 菌群とA. restrictus とは異なる増殖抑制が 考えられた。

以上のことから貯蔵トウモロコシに対するAIT蒸気に よる菌類の増殖抑制効果は, 菌の種類により異なり, トゥ モロコシの主として内部まで存在しているA. glaucus 菌 群など内在性菌類（internal fungi）に対しては抑制効果 が弱く，A. restricutus, A. penicillioidesなど主に表層部 に存在している表在性菌類（external fungi, surface fungi）については強い抑制効果が見られた.

Blanchard-Hanlin ${ }^{13)}$ はナッツ類のペカンに対してプロ ピレンオキサイドによるカビ等の増殖抑制効果に関し, 内 在性菌と表在性菌について効果に差異を認めている.

これまでの知見から，今回の一連の試験において接種菌 として $\mathrm{AF}$ 産生菌を用いたが接種方法からみて, 分生子等 が表面に付着した状態であったことから AIT蒸気の影響 を強く受けたと考えられる。

\section{ま と め}

近年干ばつによる農産物の不作が増加しており，農産物 の未成熟や昆虫等による加害を招いている。これらから力 ビおよびカビ毒污染の原因となることが桐念されている.

本研究ではカビが増殖するのに十分の条件下でAIT含 有製剂がトウモロコシに自然感染したカビ毒産生菌を含む 菌類の増殖を抑制することを明らかにした。

AIT 製剂の利用は設置方法を工夫することにより貯蔵農 産物等を多くのカビの事故から守り，カビ毒による污染な ど経済的損失を少なくすることが可能であると考えられ る.

\section{文献}

1) Uematsu, Y., Hirata, K., Suzuki, K., Iida, K., Ueda, T., Kamata, K. Determination of isothiocyanates and related compounds in mustard extract and horseradish extract used as natural food additives. Food Hyg. Soc. Jpn., 43(1), 10-17 (2002).

2) 関山泰司, 揮発性抗菌物質 (AIT) による食品保存技術. Bokin Bobai., 38(9), 617-625 (2010).

3) Inouye, S., Goi, H., Miyauchi, K., Muraki, S., Ogiwara, M., Iwanami, Y. Inhibitory effect of volatile constituents of plants on the proliferation of bacteria. J. Antibact. Antifung. Agents, 11, 609-615 (1983).

4) Isshiki, K., Tokuoka, K., Mori, R., Chiba, S. Prelimary examination of allyl isothiocyanate vapor for food preservation. Biosci. Biotechnol. Biochem., 56, 1476-1477 (1992).

5) Sekiyama, Y., Mizukami, Y., Takeda, A., Oosono, M., Nishimura, T. Effect of mustard extract vapor fungi and spore-forming bacteria. J. Antibact. Antifung. Agents, 24, 171-178 (1996).

6) Johnsson, P., Lindblad, M., Thim, A. M., Jonsson, N., Vargas, E. A., Medeiros, N. L., Brabet, C., Quaresma, de Araujo, M., Olsen, M. Growth of aflatoxigenic moulds and aflatoxin formation in Brazil nuts. World Mycotoxin Journal, 1(2), 127-137 (2008).

7) Sekiyama, Y., Mizukami, Y., Takeda, A. Corrosiveness of allyl isothiocyanate towards metals, rubbers and plastics and ability of allyl isothiocyanate vapor to permeate plastic films. J. Food Hyg. Soc. Jpn., 36, 375-382 (1995).

8）厚生労働省医薬品局食品安全部長通知「総アフラトキシン の試験法について」(食安発 0816 第 2 号平成 23 年 8 月 16 日付)

9）一色賢司，徳岡敬子，アリルイソチオシアネートによる食 品の健全性確保. Jpn. J. Food Microbiol., 10, 1-6 (1993).

10) Tsuruta, O., Gohara, S., Saito, M. Scanning electron microscopic observations of fungal invasion of corn kernels. Trans. mycol. Soc. Japan, 22, 121-126 (1981).

11) Fennell. D. I., Bothast. R. J., Lillehoj. E. B., Peterson. R. E. Bright greenish-yellow fluorescence and associated fungi in white corn naturally contaminated with aflatoxin. Cereal Chem., 50, 404-414 (1973).

12) Takahashi. H., Yazaki. H., Manabe. M., Matsuura. S. Scanning electron microscopic observation of invasion of brown and milled rice kernels with Eurotium rubrum, Aspergillus restrictus and A. versicolor. Trans. mycol. Soc. Japan, 28, 43-48 (1987).

13) Blanchard. B. O., Hanlin. R. T. Effect of propylene oxide treatment on the microflora of Pecans. Appl. Microbiol., 26, 768-772 (1973). 